\title{
Exploring Teachers' Perception of the Efficacy of ELT in Iranian Public Schools and Private Language Institutes
}

\author{
Mohammad Aliakbari (Corresponding author) \\ English Department, Ilam University, Ilam, Iran \\ E-mail: maliakbari@hotmail.com \\ Mojtaba Gheitasi \\ English Department, Ilam University, Ilam, Iran \\ E-mail: mghietasi@gmail.com
}

Doi:10.7575/aiac.alls.v.5n.2p.12

Received: 04/02/2014

URL: http://dx.doi.org/10.7575/aiac.alls.v.5n.2p.12

Accepted: 20/03/2014

\begin{abstract}
This paper intended to compare teaching English in private language institutes and public schools in Iranian Education system from the viewpoint of the English teachers who practice in both systems. It also aimed at examining teachers' preference to teach-in either place. 15 English teachers in Ilam city participated in the study and data were collected through a researcher-made questionnaire, including 60 Items through which respondents were asked to express their dis/agreement on 5 subscales. The results showed that better management, better fulfillment of the educational needs, and better teaching environment were among the reasons why the teachers preferred to teach in private language institutes. The study then, provides suggestions for improvement of ELT in the public system.
\end{abstract}

Keywords: ELT in Iran, public schools, private language institutes, teachers' preferences.

\section{Introduction}

English is spoken by over 2 billion people around the world and the number of non-native speakers of English is 3 times as much as its native speakers almost all research and publications in the international level are performed in English (Crystal, 1997; Flowerdew and Peacock, 2001). Because of its undeniable importance, the need for English as a foreign language has made governments and education systems to reconsider their programs to meet their requirements. In this relation, no doubt, evaluation plays a significant role in improving programs. It helps knowing about strengths and weaknesses of the program and, if necessary, making modifications and improvements in the curriculum.

Owing to the existence of two systems of English language education in Iran, i.e. public education in state or private schools as a compulsory course and teaching of English in private language institutes, it was considered necessary to evaluate the teaching conditions in these places from the viewpoints of teachers who perform in both systems.

\section{Review of Literature}

Several definitions have been put forward for evaluation and educators have sometimes interpreted it differently (Olivia, 2001; Ornstein and Hunkins, 2004). It is considered as providing information needed by policy makers and education planners to make appropriate decisions (Worthern and Sanders, 1998). Scriven (1991) introduced Formative and Summative evaluation as different ways of analyzing curriculum evaluation in terms of timing, instrument and purpose of the course: Formative evaluation requires providing information needed to enhance the program (Morris and FitzGibbon, 1978; Scriven, 1991; Weston, Mc Alpine and Bordonaro, 1995) and is conducted during the implementation of a program. Summative evaluation, however, is done at the end of the program to evaluate its effectiveness.

According to Erden (1995) there are a lot of different evaluation models that researchers can choose from among based on the goals and conditions of their programs. Fitzpatrick, Sanders and Worthen (1998) classify evaluation approaches as: objective oriented, management oriented, consumer oriented, expertise oriented, adversary oriented and participant oriented evaluation. The present study aimed at evaluating the program from the view of the participants.

Numerous evaluation studies have been done. Akar (2009) conducted research in Poland to find out the effectiveness of foreign language teacher training colleges (FITTC).The findings of the study showed that the FLTTCs were generally aimed at learning a foreign language and getting a better job. Also, it was revealed that the participant teachers generally had positive perceptions about their teaching in the classroom. Karahan (2007) carried out an evaluation in Yildiz Teknik University Modern Language Department to evaluate English II instruction program syllabus using teachers' and students' opinions by using context, input, process and product (CIPP) model. The results showed some significant differences between the teachers' and students' perceptions about the context, input, process and product elements of the syllabus. Likewise, Al-Darwish (2006) carried out research on the effectiveness of Kuwaiti elementary school English language teachers and supervisors. Based on the findings of the study, the Kuwaiti English language teachers strongly approved communicative language teaching. However, the actual classroom teaching was not student-centered but 
rather highly teacher-centered. Besides, the teachers, and the supervisors, would have liked more translation into Arabic be included in the official curriculum, and reading, writing, and grammar be introduced earlier in the curriculum. Also, the teachers and the researchers believed that the teachers' current level of proficiency in English language was not satisfactory.

Nam (2006) conducted a study in South Korea which focused on perceptions of college students and their English teaches in a university team-based curriculum regarding the new communication-based English curriculum and instruction in a specific university-level English program. Findings of the study demonstrated that while students generally had somewhat negative opinion about the curriculum, teachers had positive opinion about the effectiveness of the new curriculum. Moreover, findings showed that the given communication-based EFL curriculum might not comply with the students' desires, owing to several weaknesses of the curriculum itself and some already existing barriers in the institutional system behind the curriculum. Gerede (2003) carried out research on the effectiveness of curriculum renewal program at Andolue University, Intensive English Program. The purpose was to evaluate the perceived language needs of the students to follow English-medium content courses at five English-medium departments. Results showed that there were a few significant differences between the two curricula in terms of meeting the students' language needs. Based on the results, relevant suggestions were made for the curriculum renewal process. Erdogan (2005) conducted a study on evaluation of English learning at primary state schools in Turkey. Findings of the study showed that though the teachers at primary school considered the objectives and the content consistent, they did not consider it effective. Thus, in their opinion, unless some revisions were made, such a curriculum was not applicable. As for the students, they seemed to be happy with learning English at 4th and 5th grade.

Valuable studies have also been conducted on evaluation of TEFL program in Iran mostly to fulfill the requirements of MA courses. These studies (Amini, 1991; Haghverdian, 1991; Baharlooie, 1992; Amirtash, 1993; Dehbashi-Sharif, 1994; Kandi, 1995; Sadeghi, 1998) have had valuable contributions to the evaluation of TEFL and have been helpful in providing some valuable insights for further research. Yet, they have been administered to fulfill the requirements of an academic degree and have focused on issues independent from one another (Farhady \& Sajadi, 2004).

A comprehensive study by Farhady and Sajadi (2004) sponsored by the Ministry of Education attempted to evaluate the status of teaching and learning English in Iranian junior high schools. The results of the study showed that both teachers and students possessed a reasonable command of English. Another study was conducted on TEFL program evaluation by Rahimpour and Hashemi (2011) on evaluation and selection of 3 high school textbooks currently in use in Iran from the viewpoint of English language teachers. The findings made it clear that textbooks were not efficient from teachers' viewpoints regarding their five sections of vocabulary, reading, grammar, language functions and pronunciation practice. Moreover textbooks physical make up and practical considerations were not satisfactory to the teachers.

\section{Statement of the Problem}

Due to rapid increase in international relations and communications, an immediate need for English as the most important medium of communication is felt in non-English speaking countries all over the world. Thus, education systems in all countries, including Iran, put a high priority on teaching and learning English.

English is taught in Iranian junior high school and high school for 7 years until students get their diploma. They start learning English from the first grade in junior high school for three years. Then, they spend three more years in high school and one year in pre-university program. Generally English is taught for 4 hours ( 2 class sessions) in a week in each academic year. The instructional materials are textbooks developed by the Ministry of Education based on an eclectic approach, following audio-lingual, cognitive and communicative approaches to language teaching. The majority of teachers who teach in junior high schools hold an Associate Degree obtained from teacher training centers. Most high school teachers hold BA degrees in TEFL (teaching English as a foreign language), English literature or English translation. Also, a considerable number of teachers who teach in high schools or pre-university programs hold MA degrees in TEFL, English literature, English translation or English linguistics.

Although some valuable program evaluation studies have been conducted, there is not yet enough empirical evidence to judge English program in use in Iran. In the meantime, despite considerable amount of attention, money, time and energy devoted by education authorities, a positive public attitude to learning English in the Iranian public junior high schools and high schools is yet to be attained. Among the common views in this regards, there are some voices which maintain that textbooks are not efficient and only focus on reading, writing and grammar, or little attention is paid to speaking and using language(Farhady \& Sajadi, 2004). Still others criticize the teaching methods and too much focus on grammatical explanations. Reference can also be made to those who think that not enough time is allocated to teaching English in weekly school program (Rahimpour and Hashemi, 2011). Yet, due to lack of support from academic research, not sufficient empirical evidence for judgment in this regard is available.

In addition to the above mentioned state education system, a good number of private language institutes have been established in recent years that have attracted considerable public attention. Owing to the accountability in selecting teachers, textbooks, programs and extra-curricular factors, these institutes have had a successful experience in language teaching in general and English language teaching in particular. They also have provided positive attitudes in the public regarding language teaching that has made a lot of language learners to rush into these institutes, hoping to have a successful language learning experience. Stated differently, this new education system has sometimes appeared more successful and more qualified than public education system in certain areas.

Owing to the above mentioned issues, research was considered necessary to investigate the advantages and 
disadvantages of teaching in the two mentioned education systems. In particular, to examine and improve the current state of English program in Iranian education system, more research on program evaluation is required. Accordingly, the present study is to examine the working ELT programs in state and private sectors in Iran from teachers' viewpoints. Based on the above statements the following research questions have been posed:

1. What perceptions do Iranian English language teachers who perform in both private language institutes and public schools have toward (dis)advantages of teaching in either system?

2. On what bases do teachers prefer to teach in either system?

\section{Methodology}

\subsection{Participants}

The participants of the study included 15 English language teachers (10 males and 5 females) 9 of whom had BA degrees in TEFL, English literature and English translation and the other 6 had MA degrees in TEFL or linguistics from Iranian universities. Having different years of teaching experience, all the teachers were employed by Ministry of Education to teach public schools of as full-time or part-time teachers. However, they taught in private language institutes in Ilam city as part-time instructors. All the participants were indigenous people from Ilam city or surrounding areas with similar ethnic and linguistic backgrounds. They were chosen using convenient sampling considering their availability and willingness to cooperate, as they were among the colleagues of one of the researchers and were easily available and sincerely cooperated in completing the questionnaire. Variety in participants' gender, education level and teaching experience were significant enough to form a representative sample.

\subsection{Instrument}

The instrument used in this study was a 60-item questionnaire made by the researchers in winter 2011. It aimed at investigating the viewpoints of the teachers who participated in the study regarding the status of TEFL in the two systems already discussed and their preferences for teaching in either public schools or private language institutes. The instrument addressed issues like the role of management in education enhancement, effectiveness of the textbooks and extracurricular material, the degree of students' and teachers' satisfaction of the educational environment, and the type or quality of the educational facilities. The validity of the questionnaire was confirmed through expert judgment by two assistant professors from Ilam University. The reliability of the questionnaire was calculated using Cronbach Alpha index at 0.82 .

\subsection{Procedure}

Prior to the development of questionnaire, a pilot study was conducted by researchers through which 10 English teachers in both public schools and private language institutes were consulted on the particular aspects of both systems in winter 2011.The 60-item questionnaire was categorized into five scales of Educational Management, Educational Needs, Educational Facilities, Teaching Material and Educational Environment (Atmosphere). After different modifications, reforms and revisions by different colleagues, including two researchers in social sciences, the questionnaire was finalized in Likert format, with five options of fully agree, agree, neutral, disagree and fully disagree. For the ease of analysis, values were assigned; fully agree $=5$, agree $=4$, neutral $=3$, disagree $=2$ and fully disagree $=1$ in favor of private language institutes. For items in favor of public schools, the values were assigned in the opposite direction, i.e. they have been reverse valued. Then the collected data were analyzed using statistical package for social sciences (SPSS).

To record the percentage of the responses, multiple response statistics for the 5 categories were calculated.in addition, to examine if there is any difference between the participants' opinion in the four categories of educational needs, educational facilities, teaching material and educational atmosphere or environment paired-Sample T-test was run. However, due to the nature of the items in the questionnaire it was not possible to adopt paired-Sample T-test for the category of educational management.

\section{Results}

To obtain the results, multiple response statistics and paired-Sample T-test for the 5 categories were calculated at $(\mathrm{p}<0.05)$ level of significance. The statistical analyses and the explanation of the findings are presented in tables below. Based on the multiple response statistics (Table 1); almost $77 \%$ of the subjects agreed that educational management in private language institutes is performed better than that of public schools; Based on the paired samples T-test (Tables 4) for the category of Educational needs, $(\mathrm{t}=14.53, \mathrm{df}=14, \mathrm{p}=.000)$, there is significant difference between the subjects' perception toward the category of educational needs in private language institutes and public schools. For the category of educational facilities (Tables 2, 3 and 4$),(\mathrm{t}=.939, \mathrm{DF}=14, \mathrm{p}=.364)$, there is not a significant difference in the teachers 'perception toward facilities. Regarding the category of teaching material (Tables 2, 3 and 4), $(\mathrm{T}=8.686$, DF $=14, \mathrm{p}=.000$ ), there is significant difference between the teachers' perception toward teaching in private language institutes and public schools. Similarly, for the category of educational atmosphere (Tables 2, 3 and 4) there is a significant difference in the teachers' perception toward the educational atmosphere in private language institutes and public schools, $(\mathrm{t}=4.803, \mathrm{DF}=14, \mathrm{p}=.000)$. 
Table 1. Multiple Response statistics for the five categories

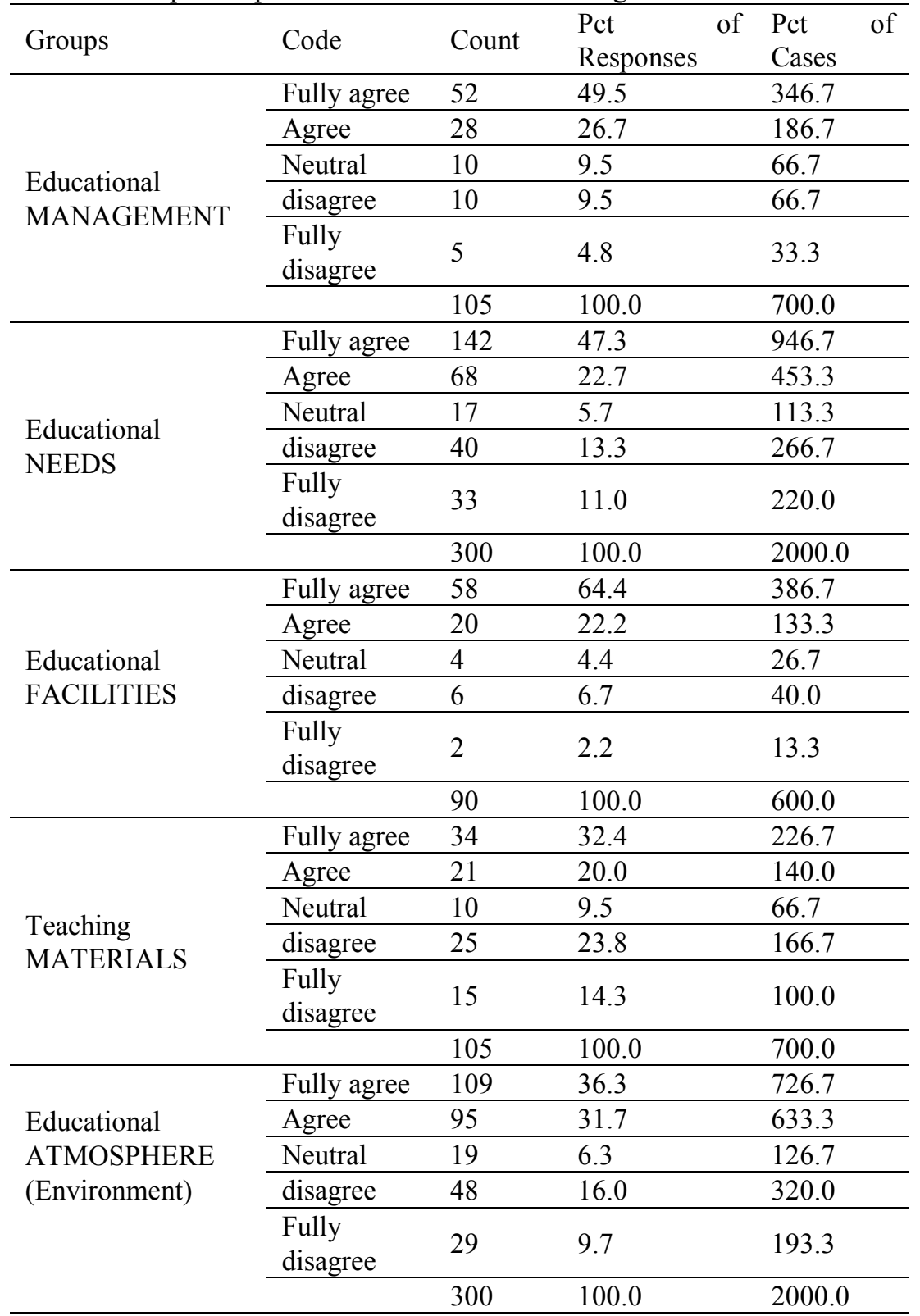

Table 2. Paired Samples Statistics for different categories

\begin{tabular}{lllll}
\hline & Mean & $\mathrm{N}$ & $\begin{array}{l}\text { Std. } \\
\text { Deviation }\end{array}$ & $\begin{array}{l}\text { Std. } \\
\text { Error } \\
\text { Mean }\end{array}$ \\
\hline $\begin{array}{l}\text { S. Educational } \\
\text { Needs }\end{array}$ & 3.6667 & 15 & .22254 & .05746 \\
\hline $\begin{array}{l}\text { P. Educational } \\
\text { Needs }\end{array}$ & 1.6844 & 15 & .44754 & .11556 \\
\hline $\begin{array}{l}\text { S. Educational } \\
\text { Facilities }\end{array}$ & 1.5111 & 15 & .43400 & .11206 \\
\hline $\begin{array}{l}\text { P. Educational } \\
\text { Facilities }\end{array}$ & 1.6889 & 15 & .66029 & .17049 \\
\hline S. Atmosphere & 3.0778 & 15 & 1.05196 & .27161 \\
\hline P. Atmosphere & 1.9810 & 15 & .52521 & .13561 \\
\hline $\begin{array}{l}\text { S. Teaching } \\
\text { Material }\end{array}$ & 3.8333 & 15 & 1.11270 & .28730 \\
\hline $\begin{array}{l}\text { P. Teaching } \\
\text { Material }\end{array}$ & 2.2133 & 15 & .53701 & .13866 \\
\hline
\end{tabular}


Table 3. Paired Samples Correlations for different categories

\begin{tabular}{lllllll}
\hline & & & $\mathrm{N}$ & $\begin{array}{l}\text { Correlati } \\
\text { on }\end{array}$ & Sig. \\
\hline $\begin{array}{l}\text { Pair } \\
1\end{array}$ & $\begin{array}{l}\text { S. Educational Needs \& } \\
\text { Needs }\end{array}$ & & & & & \\
\hline $\begin{array}{l}\text { Pair } \\
1\end{array}$ & $\begin{array}{l}\text { S. Educational } \\
\text { Educational Facilities }\end{array}$ & 15 & -.147 & .602 \\
\hline $\begin{array}{l}\text { Pair } \\
1\end{array}$ & $\begin{array}{l}\text { S. Teaching Material \& } \\
\text { Material }\end{array}$ & P. Teaching & 15 & .841 & .000 \\
\hline $\begin{array}{l}\text { Pair } \\
1\end{array}$ & S. Atmosphere \& P. Atmosphere & & 15 & .151 & .590 \\
\hline
\end{tabular}

Table 4: Paired Samples Test for different categories

\begin{tabular}{|c|c|c|c|c|c|c|c|c|}
\hline & \multicolumn{5}{|c|}{ Paired Differences } & \multirow{3}{*}{$\mathrm{t}$} & \multirow{3}{*}{$\mathrm{df}$} & \multirow{3}{*}{$\begin{array}{l}\text { Sig. } \\
(2 \\
\text { tailed })\end{array}$} \\
\hline & \multirow[t]{2}{*}{ Mean } & \multirow[t]{2}{*}{ Std. Deviation } & \multirow[t]{2}{*}{$\begin{array}{l}\text { Std. Error } \\
\text { Mean }\end{array}$} & $\begin{array}{l}95 \% \\
\text { Interval } \\
\text { Difference }\end{array}$ & $\begin{array}{l}\text { Confidence } \\
\text { of the }\end{array}$ & & & \\
\hline & & & & Lower & Lower & & & \\
\hline $\begin{array}{l}\text { S. Educational Needs } \\
\text { P. Educational Needs }\end{array}$ & 1.9822 & .52823 & .13639 & 1.6897 & 2.2747 & 14.534 & 14 & .000 \\
\hline $\begin{array}{l}\text { S. Educational Facilities } \\
\text { P. Educational Facilities }\end{array}$ & .1778 & .73319 & .18931 & -.2282 & .5838 & .939 & 14 & .364 \\
\hline $\begin{array}{l}\text { S Teaching Material } \\
\text { P. Teaching Material }\end{array}$ & 1.6200 & .72230 & .18650 & 1.2200 & 2.0200 & 8.686 & 14 & .000 \\
\hline $\begin{array}{l}\text { S. Atmosphere } \\
\text { P. Atmosphere }\end{array}$ & 1.0968 & .88451 & .22838 & .6070 & 1.5866 & 4.803 & 14 & .000 \\
\hline
\end{tabular}

\section{Discussion}

This study intended to investigate perceptions of the English language teachers who teach in both public schools and private language institutes; additionally, it aimed at exploring the reasons why the teachers preferred to teach in one or the other.

Based on the results Educational Management was an influential factor in success of the students, teachers and EFL program (Tables 1 and 4). According to the answers to individual items included in the questionnaire, since in private language institutes the managers plan for only one module, they can act better (100\% agree). In private language institutes the managers can give a placement test and put the students in proper level in the program (87\% agree). Also in private institutes teachers are free from strict regulations in public schools and can be more accountable (93\% agree; $7 \%$ neutral).However, in public schools they have to put all students with different levels in the same class and teach all of them in the same way ( $93 \%$ agree).

Educational Needs were another influential factor for the teachers (Tables 1 and 4). As students choose to attend private institutes in their will, they are more motivated (93\% agree). They have more opportunities to ask questions ( $93 \%$ agree; $7 \%$ neutral). Also, students are not there to get a degree ( $86 \%$ agree; $7 \%$ neutral). Teachers should improve their knowledge because they are exposed to more questions from their students ( $100 \%$ agree). In private institutes, teachers have more freedom to work on their own initiatives but in public schools they have to follow the fixed framework of the books developed by Ministry of Education ( $74 \%$ agree; $13 \%$ neutral).

Still another factor was teaching Materials (Tables 1 and 4). Books developed by Education Ministry focus more on reading, writing, vocabulary and grammar (100\% agree); they are not up to date with new findings of second language acquisition ; not well-organized and do not fulfill Educational Needs (100\% agree). However, the books introduced by private language institutes were considered up to date, have a better content, equally focus on all four skills, and are well-organized and more coherent ( $74 \%$ agree; $13 \%$ neutral).

Another important factor was Educational Atmosphere (Tables 1 and 4). Private language institutes have a less formal atmosphere compared with public schools and teachers are more friendly (60\% agree); they have more freedom to start and finish the class (87\% agree); both teachers and students make the best use of their class time (93\% agree, $7 \%$ neutral); there are fewer students in the class and more time for the teacher to deal with all students and for every student to participate in class activities (87\% agree); teachers have the opportunity to speak English more and use language to communicate and so enjoy teaching ( $86 \%$ agree, $7 \%$ neutral). 
Although, all of the teachers agreed that better equipment like computers, CD players, TVs and extra-curricular books are provided in private language institutes in Ilam (100\% agree); Educational Facilities were not among influential factors on their preference to teach in either system (Tables 1 and 4). All of them (100\% agree) specified that public schools have larger space than private language institutes but the equipment in private language institutes is better. Only $47 \%$ agreed with better payment in private language institutes (47\% agree, $13 \%$ neutral). Most of them (74\% agree, $13 \%$ neutral)mentioned that years of experience result in better payment in public schools but private language institutes it is not the case. All of them (100\% agree) contended that teaching in public schools is sustainable, has job stability and involves insurance.

\section{Conclusion}

Teacher can be the most important factor in every class. Therefore, the ideas and experiences of teachers, who are the most-directly- involved educators in the class activities are valuable information that can be considered for the efficacy and efficiency of the education. The main incentive for the teachers in preferring teaching in private language institutes, based on the findings of the study, is lack of accountability and freedom to administer the class the way they seem the best; and unavailability of a revised textbook that fulfills current educational needs of the students. Improving teachers' speaking, using language and making students communicate in English is one of the desires of the teachers, a factor that has received little attention in teaching English in Iranian public education system. What is important for all of these teachers is a better program, up to date and revised material, more freedom to follow the course based on their own preferences, a less crowded class and an atmosphere full of communication and collaboration among the teacher and students in the class. Despite the fact that in public schools, teachers have job stability, better income and a less demanding job, due to the above mentioned problems, these teachers prefer to teach in private language institutes. It is hoped that the present and the coming studies be helpful and educators and educational planners prevent unnecessary loss of the educational capitals in the country.

\section{Implications of the study}

Findings of this study may offer insights for all educational stakeholders in the public education system in Iran, including policy makers, educational planners, syllabus designers, educators, instructors, parents, learners and the public. Policy makers and educational planners are expected to determine appropriate policies for education at large, including foreign language teaching. The length and quality of instruction, the quality of the syllabus, the qualification of the teachers, the extent of teacher instruction, the consistency and length of in-service instruction can be enhanced in the educational system. The findings of this study would be helpful for policy makers and educational planners to improve, of course with cooperation of educators, teachers and students, the current attitudes toward learning English language and move the trend of English teaching away from focusing on traditional Grammar Translation mode of teaching toward more communicative and interactive modes. Also, the findings of this study may help education planners and educators to investigate the ways to improve the quality of textbooks and the length and quality of instructions and pave the way to improve the qualifications of teachers with proper in-service training by implementing proper strategies and employing qualified teachers.

\section{Limitations}

This study was a step toward evaluating English language teaching in Iran and no doubt has some limitations. This study administered in context of Ilam; and it may not be easy to generalize the findings nationwide. Also, number of the participants is relatively low to rely on its generalizability. It is hoped that later studies with a higher number of participants and a wider context reach better achievements.

\section{References}

Akar, H. (2009). Foreign language teacher education: The Polish case. The New Educational Review, 17(1), 185-211.

Al-Darwish, S. (2006). An investigation of teachers' perceptions of the English language curriculum in Kuwaiti elementary schools. Unpublished doctoral dissertation, University of Denver, the USA.

Amini, Z. (1991). A general evaluation of four high school English textbooks used in Iran. Unpublished MA thesis, Tehran: Islamic Azad University, Central branch.

Amirtash, K. (1993). Factors influencing students in Iranian junior high schools as conceived by students and teachers. Unpublished MA thesis, Tehran: Islamic Azad University.

Baharlooie, R. (1992). The correlation between grammatical structures taught by the teacher and learned by students: an evaluation of the end of a GPE course. Unpublished MA thesis, Tehran: Islamic Azad University, Central branch.

Cronbach, L. J. (1963). Course improvement through evaluation, Teachers College Record, 64, 73-672.

Cronbach, L. J. (1982). Designing Evaluations of Educational and Social Programs. San Francisco, Jossey-Bass.

Crystal, D. (1997). English as a global language. Cambridge: Cambridge University Press.

Flowerdew, J., \& Peacock, M. (2001). (Eds.). Research perspectives on English for academic purposes, Cambridge: CUP.

Dehbashi-Sharif, F. (1994). The effect of learning English at elementary school age on the succeeding educational achievement in this subject. Unpublished MA thesis, Tehran: Islamic Azad University, Central branch. 
Erden, M. (1995). Eğitimde program de ğ erlendirme: Ankara: Pegem Yay incilık.

Erdogan, V. (2005). An evaluation of the English curriculum implemented at the 4th and 5th grade primary state schools: The views of the teachers and the students. Unpublished MA thesis, Mersin University, Mersin.

Farhady, H., \& Sajadi, F. (2004). Evaluation of students' English language achievement in Iranian junior high schools. Journal of Social Sciences \& Humanities of Shiraz University, 21(1), $42-54$.

Gerede, D. (2005). A curriculum evaluation through needs analysis: Perceptions of intensive English program graduates at Anadolu University. Unpublished MA thesis, Anadolu University, Eskisehir.

Haghverdian, A. (1991). Communicative needs and objectives in teaching reading to high school and university students. Unpublished MA thesis, Tehran: Islamic Azad University, Central branch.

Kandi, M. J. (1995). Comparing DM and TM in teaching reading comprehension to Iranian high school students. Unpublished MA thesis, Tehran: Islamic Azad University, Central branch.

Morris, L. L., \& Fitz-Gibbon, C. T (1978). Evaluator's handbook. California: Sage.

Nam, J.M. (2005). Perceptions of Korean college students and teachers about communication-based English instruction: Evaluation of a college EFL curriculum in South Korea. Unpublished doctoral dissertation, the Ohio State University, the USA.

Olivia, F. P. (2001). Developing the curriculum. New York: Longman.

Ornstein, Allan C., \& Hunkins Francis P. (2004). Curriculum: Foundations, principles and issues. Englewood Cliffs, NJ, Prentice Hall.

Rahimpour, M. \& Hashemi, R. (2011). Textbook selection and evaluation. World Journal of Education, 1(2); 62-68.

Sadeghi, F. (1998). An evaluation to the first grade English textbook in the current new system of education at high school in Iran, Unpublished MA thesis, Tehran: Islamic Azad University, Central branch.

Scriven, M. S. (1991).Evaluation Thesaurus $\left(4^{\text {th }}\right.$ Ed.). Beverly Hills, California: Sage.

Weston, C., McAlpine, L., \& Bordonaro, T. (1995). A model for understanding formative evaluation in instructional design. Educational Technology Research and Development, 43(3), 29-46.

Worthen, R., \& Sanders, R. (1998). Educational evaluation: Alternative approaches and practical guidelines. New York: Longman. 